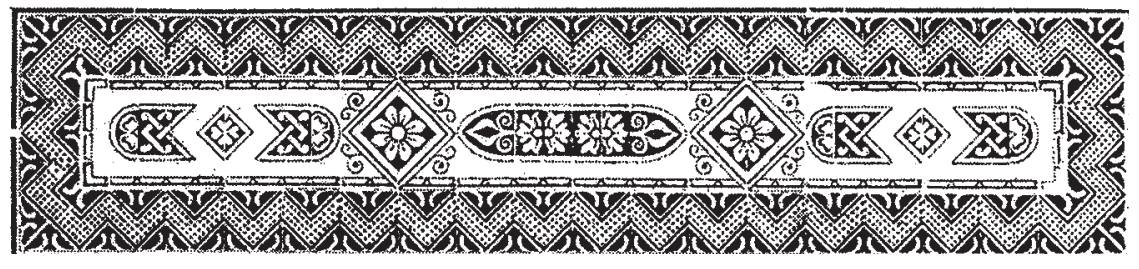

УДК 726

https://doi.org/10.18485/bratstvo.2017.21.6

\title{
НОВООТКРИВЕНА РАНОХРИШПАНСКА БАЗИЛИКА НА ПРОСТОРУ СЕВЕРОИСТОЧНЕ БОСНЕ И ХЕРЦЕГОВИНЕ
}

\begin{abstract}
У тексту се даје приказ досадашњих археолошких истраживања на локалитету Црквине, у селу Мраморак, општина Осмаци, у Републищи Српској. Рад садржи опиирнији увод у коме се наводе касноантички локалитети у североисточној Босни и Херцеговини. Централни део рада представља опис и анализу остатака ранохришћанске двобродне базилике откривене на локалитету Црквине. Посебан део овог рада посвећен је римском надгробном споменику (стели) из периода принципата, а који је и најзначајнији налаз овог локалитета. Натпис на овом споменику је делимично сачуван и захваљујући др Амри Шачић транскрибован.
\end{abstract}

Научно - истраживачким радом по питању најстарије историје хришћанства, те самим тиме и касноантичких цркава, односно базилика као његових најрепрезентативнијих остатака на простору Босне и Херцеговине, кроз историографију су се бавила многа еминентна имена. Пионири у овој области били су научници који су дошли заједно са аустроугарском окупацијом Босне и Херцеговине 1878. године, а међу њима се издвајају Вјенцеслав Радимски (Vaclav Radimsky)',

${ }^{1}$ Vaclav Radimsky, Ostanci rimskih naseobina u Šipragi i Podbrgju, zatim starobosanski stećci u Šipragi i uz Vrbanju u Bosni, GZM, god. IV, Sarajevo, 1892, 75-80; 372-387. 
Ћиро Трухелка ${ }^{2}$ и Карл Пач (Carl Patsch) $)^{3}$. Иако се током XX вијека велики број научника бавио овим аспектом историје, због самог карактера рада није могуће набројати све њих. Међутим, као прве међу једнакима свакако треба издвојити Димитрија Сергејевског чији су радови на тему касноантичких базилика умногоме допринијели бољем разумевању ове проблематике, ${ }^{4}$ затим Ђуру Баслера, поред чијих многобројних радова треба истаћи његове двије синтезе које су доживеле више издања, ${ }^{5}$ Томислава Анђелића чији се немјерљив допринос овој проблематици повезује с његовим истраживачким радом на базиликама у Циму и Житомислићима, ${ }^{6}$ те Вељка Пашквалина чији су радови и студије на ову тему обједињени у оквиру књиге Kršćanstvo kasne antike u zaleđu Salone i Narone - Arheološka istraživanja kasnoantičkog kršćanstva u Bosni i Hercegovini ${ }^{7}$.

На простору данашње Босне и Херцеговине укупно се налази више од седамдесет локалитета на којима су пронађени остаци хришћанске сакралне архитектуре, односно касноантичких базилика. ${ }^{8}$ За више од двије трећине ових налаза може се, са највећом сигурношћу, рећи да припадају остацима дотичних објеката, јер су на тим локалитетима пронађени конкретни докази попут самих темеља базилика, затим дијелови каменог намјештаја, те бројни други, већи или мањи арте-

${ }^{2}$ Ćiro Truhelka, Prilozi rimskoj arheologiji Bosne i Hercegovine, GZM, god. IV, Sarajevo 1892, 340-355.

${ }^{3}$ Carl Patsch, Epigrafsko pabirčenje, GZM, god. VII, Sarajevo, 1895, 285-292.

${ }^{4}$ Dimitrije Sergejevski, Starohrišćanska bazilika u Klobuku, GZM, arheologija, Sarajevo, 1956; Dimitrije Sergejevski, Bazilika u Dabravini (Revizija), GZM, arheologija, posebno izdanje, Sarajevo 1956; Dimitrije Sergejevski, Bazilika u Mokrom, GZM, arheologija, Sarajevo, 1961, 211-228.

${ }^{5}$ Đuro Basler, Arhitektura kasnoantičkog doba u Bosni i Hercegovini, Sarajevo, 1972; Đuro Basler, Spätantike und frühchristliche Architektur in Bosnien und der Herzegowina, Wien, 1993; Đuro Basler, Kršćanska arheologija, Crkva na kamenu, Mostar, 1986; Đuro Basler, Kršćanska arheologija (II izdanje), Crkva na kamenu, Mostar, 1990.

${ }^{6}$ Tomislav Anđelić, Kasnoantička bazilika u Cimu kod Mostara, GZM, arheologija, Sarajevo, 1974, 179-244; Tomislav Anđelić, Kasnoantičke bazilike u Cimu i Žitomisličima kod Mostara, Arheološki vestnik 29, Ljubljana, 1978, 629-640; Tomislav Anđelić, Neki objekti kasnoantičke sakralne arhitekture u okolici Mostara, Dolina rijeke Neretve od prethistorije do ranog srednjeg vijeka (Znanstveni skup, Metkić 4-7. X 1977. god.), Hrvatsko arheološko društvo, Split, 1980, 257-266.

${ }^{7}$ Veljko Paškvalin, Kršćanstvo kasne antike u zaleđu Salone i Narone - Arheološka istraživanja kasnoantičkog kršćanstva u Bosni i Hercegovini, Sarajevo, 2003.

${ }^{8}$ Edin Veletovac, Provincija Dalmacija u V stoljeću, magistarski rad, Sarajevo, 2013, 91-143; Edin Veletovac, Kasnoantičke bazilike u Bosni i Hercegovini, Radovi, knjiga, XVII/3, Sarajevo, 2014, 277-299. 
факти који потврђују ову чињеницу. Мањи проценат заузимају локалитети за које постоји изузетно велика или барем реална могућност да се на њима налазе остаци ових сакралних објеката, али услијед различитих разлога то никада није дефинитивно утврђено. ${ }^{9}$ Присутни трагови, као и пратећи налази дају веома јаке индиције за тако што, па је зато највјероватније само питање времена када ће то и дефинитивно постати чињеница. Постојање више од седамдесет локалитета који се везују за ранохришћанске цркве представља једну сасвим респектабилну бројку, али што је још важније је то да она, сасвим сигурно, није дефинитивна. Наиме, број пронађених касноантичких цркава непрестано расте и није питање да ли их има, већ времена када ће се оне открити. ${ }^{10}$ Убједљиво највећи број ових сакралних објеката потјече са простора средње Босне, те западне Херцеговине. Дијаментрално супротно томе, подручје сјеверне, односно сјевероисточне Босне, оваквом врстом грађевина је изузетно сиромашно. ${ }^{11}$ Посебно ова чињеница важи за простор североисточне Босне, где све до сада није био евидентиран нити један налаз ранохришћанских базилика. Разлози за то су бројни, али је узрок пре свега потребно тражити у хроничном недостатку систематских археолошких истраживања кроз комплетан период XX вијека, па све до данас.

Касноантичке цркве, тј. базилике на простору данашње Босне и Херцеговине у односу на сусједну приморску област карактеризира неколико заједничких особина. Првенствено, оне су углавном релативно мањих размјера, а у великом броју примјера странице грађевина су готово једнаке дужине, односно имају облик квадрата, а не стандардног правоугаоника. Техника градње је била на веома ниском нивоу, па су претежно зидане неуредно и то од сполија са старијих објеката и паганских надгробних споменика. Овакви зидови су најчешће били омалтерисани, а ријетко када осликани. На низак ниво технике градње указује и то што им зидови, веома често, одударају од правог угла, док су углавном оријентирани у правцу исток - запад. Ове сакралне објекте веома често прате гробнице на свод и оне представљају један од њихових најдосљеднијих пратећих додатака. Вели-

\footnotetext{
${ }^{9}$ О томе више: Edin Veletovac, Provincija Dalmacija $u$ V stoljeću (rukopis magistarskog rada), Sarajevo, 2013, fusnote, 267, 285, 334, 345, 354.

${ }^{10}$ Видети нпр. недавно откривену базилику у Бакинцима. Бојан Вујиновић, Рановизантијске базилике у Бакиниима, Бања Лука, 2014.

${ }^{11}$ Све донедавно и открића у Бакинцима, те још од раније познатог локалитета у Рамићима код Бања Луке, у наведеним областима није било евидентираних касноантичких цркава.
} 
ки број касноантичких базилика унутар или поред себе крије једну или више оваквих гробница.

Када је у питању конкретно простор општине Осмаци и самог мјеста Мраморак, који се обрађује у овом раду, овдје до сада нису регистровани никакви касноантички археолошки трагови. ${ }^{12}$ Ипак у већим административним цјелинама (Калесија и Зворник), а које се налазе у њеном сусједству, стање на терену је битно другачије. Тако се на локалитету Градина у Горњој Петровици, код Калесије, налази мање касноантичко утврђење од којег су приметни камени зидови везани кречним малтером, док су од ситнијих налаза ту пронађени уломци римских посуда, врх жељезне стријеле, као и један излизани бакрени новчић из римског периода. ${ }^{13}$

За разлику од Калесије, у околини Зворника је евидентирано много више локалитета из каноантичког периода. У мјесту Кучић кула, на локалитету Бандера откривене су двије јаме античког каменолома у којима је пронађен камени саркофаг без поклопца, затим дијелови база, те више других, у обради недовршених блокова. ${ }^{14}$ Недалеко од овог мјеста, у селу Дардагани, на локалитету Сиге, у трећој јами која је била део овог истог античког каменолома, откривено је неколико касноантичких налаза, од којих се свакако издваја споменик митраистичког култа на којем је у каменом рељефу приказана тауроктонија. ${ }^{15}$ Поред тога, овдје су још пронађени дијелови стубова, необрађених камених блокова, саркофага, фрагмената римске керамике, фибула,

${ }^{12}$ Ипак, вриједи напоменути да се на градини Косовачи, која данас припада општини Осмаци налазила прахисторијска утврда, коју су Римљани по доласку на ове просторе модифицирали и надоградили према својим потребама. На платоу у унутрашњости утврде, налазе се остаци мањих објеката које су Римљани саградили након што су преузели контролу над истом. За више информација вид. Vaclav Radimsky, Arheološke crtice, GZM, god. VII, Sarajevo, 1895, 220-222; Franjo Fiala, Prilozi arheologiji Bosne i Hercegovine, GZM, god V, Sarajevo, 1893, 152-153.) До када је ово утврђење наставило бити у употреби не може се ништа поуздано рећи, с обзиром да накнадна истраживања никада нису била предузета. Међутим, имајући у виду бројне друге локалитете са простора Босне и Херцеговине и континуитет насељености на њима, не треба одбацити могућност да је и Градина Косовача била оперативна до дубоко у период касне антике.

${ }^{13}$ Vaclav Radimsky, Arheološke crtice iz Bosne i Hercegovine, GZM, god. V, Sarajevo 1893, 483-484.

${ }^{14}$ Ivo Bojanovski, Iz rada Arheološkog referata Zavoda, Naše starine, XI, Sarajevo, 1967, 193.

${ }^{15}$ Milica D. Kosorić, Spomenik Mitrinog kulta iz okoline Zvornika, Članci i građa za kulturnu istoriju istočne Bosne, knj. VI, Tuzla, 1965, 49-56. 
жељезних алатки, као и неколико бронзаних новчића Валентинијана I (Flavius Valentinianus Augustus, вл. 364. - 375. год.) који овај локалитет највјероватније датирају у другу половину IV века. На Грацу у Брањеву евидентирани су остаци римског насеља где су уочавају зидови једног објекта, а постоји могућност да се ту налазила и једна мања античка утврда поред које је пролазила римска цеста. ${ }^{16}$ На локалитету је пронађено и неколико ситних налаза од којих вриједи издвојити жељезни трнокоп, сребрну здјелицу, као и надгробни анепиграфски споменик. Остаци касноантичког рефугиума пронађени су на Градини у Сапни, гдје се на врху бријега огледају слабо грађени зидови, као и фрагменти тамносиве керамике. ${ }^{17}$ На Кућишту у месту Доњи Шепак, пронађени су остаци једне веће грађевине чије су димензије биле око 80 х 40 м. Иако се не може поуздано утврдити, највјероватније се ради о римској вили rustici из периода III-IV вијека. ${ }^{18}$ Локалитет Улице у Шетићима такође у себи крије остатке римског насеља. На њивама се опажају остаци зидова, керамике и камена, а који датирају из периода V-VI века. ${ }^{19}$ На локалитету Ограда у Дивићима наилази се на још једно касноантичко утврђење мањих димензија. Од истог су примјетни дијелови зидова, као и камене степенице у које је био уграђен жртвеник с посветом Јупитеру. ${ }^{20}$ Једини налаз из ове области који би сугерисао на постојање касноантичке хришћанске архитектуре пронађен је на локалитету Замлаз код Зворника. У питању је једна касноантичка гробница на свод, али без клина, која се оквирно датира у период између IV-VI вијека. ${ }^{21}$ Откриће ове гробнице би можда пружало индиције да се негдје у близини налазе остаци касноантичке цркве. Таква могућност је сасвим реална, али у недостатку систематског

${ }^{16}$ Eduard Vorliček, Rimske starine u Branjevu, kotar Zvornički, GZM, god. VIII, Sarajevo, 1896, 197-199; Ivo Bojanovski, Prilozi za topografiju rimskih i predrimskih komunikacija i naselja u rimskoj provinciji Dalmaciji (s posebnim obzirom na područje Bosne $i$ Hercegovine), Prilog proučavanju antičkih naselja i kominikacija u istočnoj Bosni, Godišnjak, knj. XIX, Sarajevo, 1981, 153.

${ }^{17}$ Đuro Basler, Gradina, Sapna, Zvornik, Arheološki leksikon, tom II, Sarajevo, 1988, $72-91$.

${ }^{18}$ Veljko Paškvalin, Kučište, Donji Šepak, Zvornik, Arheološki leksikon, tom II, Sarajevo, $1988,123=98$.

${ }^{19}$ Irma Čremošnik, Ulice, Šetići, Zvornik, Arheološki leksikon, tom II, Sarajevo, 1988, $227=98$.

${ }^{20}$ Dimitrije Sergejevski, Epigrafske bilješke, GZM, god LIII, Sarajevo, 1941 (1942), 3-4.

${ }^{21}$ Ivo Bojanovski, Iz rada Arheološkog referata Zavoda, 193. 
археолошког истраживања и било каквих директних доказа, ипак смо осуђени само на претпоставку.

На основу презентираних информација јасно је да је подручје данашње општине Осмака у касно римско и непосредно постримско доба гравитирало зворничком крају гдје је до сада пронађено више римских насеља и које је прилично богато локалитетима, те археолошким материјалом из касноантичког раздобља. Остаци насеља такође говоре да су на овом подручју морале живјети организоване хришћанске заједнице с успостављеним црквеним устројем, а то би даље довело до сасвим логичког закључка да је на простору североисточне Босне, око Калесије, а поготово Зворника, морао постојати и одређен број касноантичких базилика.

\section{Един Велетовац}

\section{Опис базилике}

„Наша домовина Херцег-Босна, крије многе старине. Једне на површљу земље зуб времена намило сатире на наше очи, друге у земљи чекају ускрснуће; једне се разнашају којекуда, а ми баш домородци стојимо савијених руку, па мирно гледамо то. То је, вјера и бог, за нас брука и срамота. Пропадају нам старине, из којих се познајемо ми и преци наши."22

Овим речима Петар Мирковић започиње своје излагање у првом броју „Гласника Земаљског музеја Босне и Херцеговине”, давне 1889. године. Данас, 128 година касније, мало шта се заиста променило. Наше старине и даље пропадају, док оне старине у земљи и даље чекају неко боље време како би угледале светлост дана.

Сва нова истраживања, као и заштита постојећих, углавном зависе од иницијативе и личног залагања појединих ентузијаста. Један од њих је и Жељко Божић, парох Осмачки. Свештениковим залагањем, 2013. године, покренута су археолошка ископавања у малом планин-

\footnotetext{
${ }^{22}$ Petar Mirković, Manastir Panagjur, GZM, god. I, Sarajevo, 1889, 12.
} 
ском селу Мраморак, у општини Осмаци, на месту које народ назива Црквине..$^{23}$

Мраморак се налази на око 5 километара јужно од Осмака и обилује материјалним остацима из прошлости. Село је смештено на источној падини планине Кик, на чијем врху се налазе остаци тврђаве, а коју мештани села називају Градина. Велика некропола стећака западно од Градине, само је једна од четири скупине стећака који се

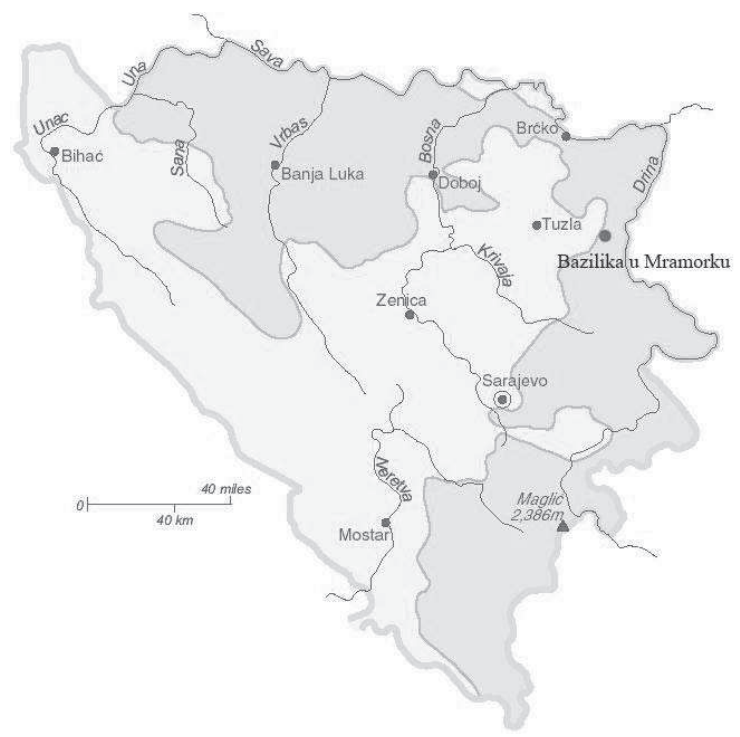
налазе у реону села Мраморак. Ова чињеница јасно указује на насељености овог краја у средњем веку. Приликом рекогносцирања терена, 4. априла 2017. год. Установљено је постојање калдрмисане цесте на локалитету Суљине воде, око 900 метара северозападно од Градине. Траг ове цесте, која се може пратити у дужини од око 2 километра, нестаје на уласку у село Лике.

Локалитет Црквине налази се североисточно од Градине, од које је удаљен око 200 метара.

Уз финансијску подршку општине Осмаци, 2015. год. археолошка истраживања на локалитету Црквине је преузео стручни тим Музеја Семберије из Бијељине, под вођством мр Мирка Бабића, а у сарадњи са музејским саветником Народног музеја у Ужицу, из Републике Србије, мр Љиљаном Мандић. Тада је потврђено да се на локалитету Црквине налазе остаци двобродне ранохришћанске базилике.

\footnotetext{
${ }^{23}$ Општина Осмаци је мала постдејтоновска општина, која се налази у североисточном делу Републике Српске. Заузима површину од 78, 67 км². Име је добила по највећем селу које је и центар општине. На истоку се општина Осмаци граничи са општином Зворник, на југу са општином Шековићи, док се на западу и северу од Осмака пружа територија општине Калесија. Рајко Бошковић, Монографија општине Осмаичи, Зворник, 2013, 17.
} 
Међутим, услед недостатка материјалних средстава истраживања су прекинута. Резултати тих истраживања нису објављени и стављени на увид стручној јавности.

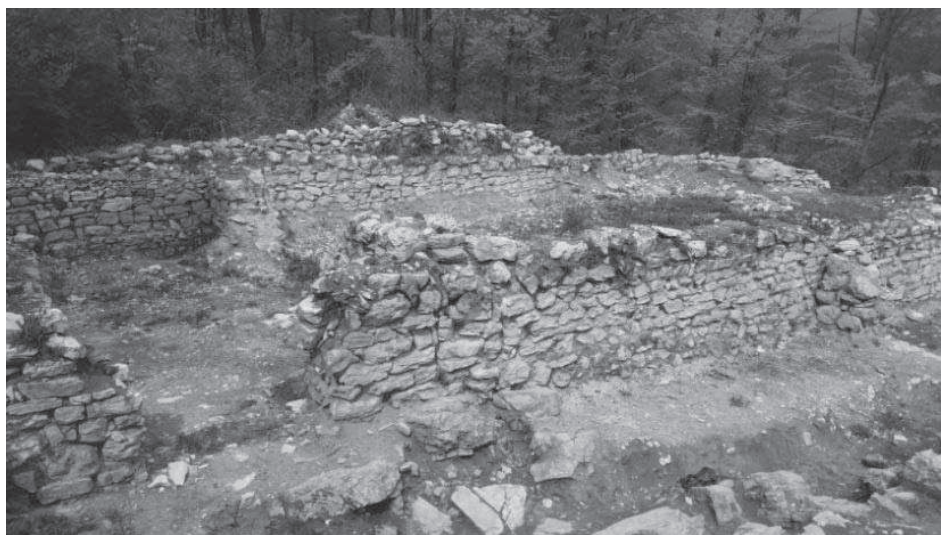

Сл. 2. Поглед на базилику са јужним и западним бродом

Такође, нису обављени конзерваторски радови, што за резултат има пропадање базилике. Циљ овог рада јесте да се широј стручној јавности прикажу резултати досадашњих истраживања и подстакну нова археолошка ископавања, која ће нам омогућити да стекнемо бољу представу о овом, до сада непознатом локалитету.

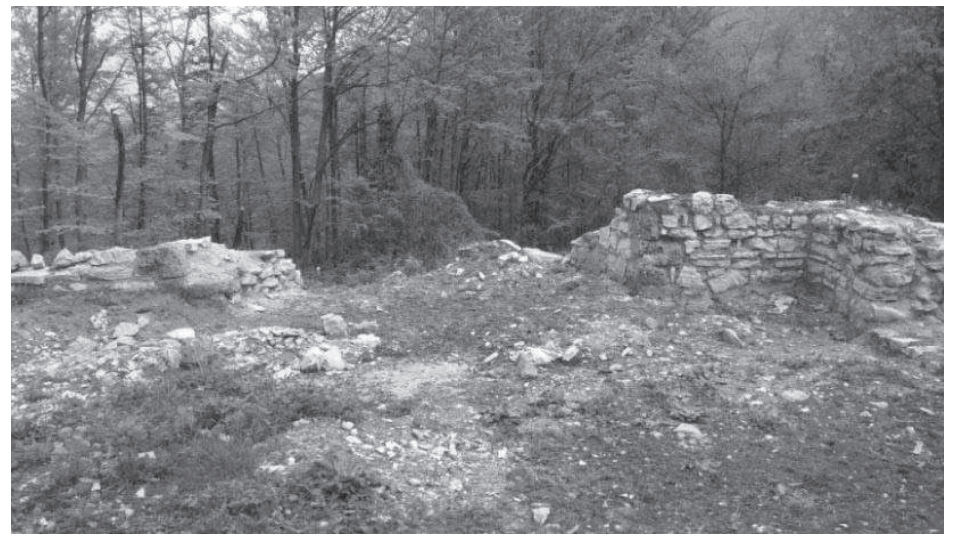

Сл. 3. Олтарски део базилике 
Базилика се простире у правцу запад - исток и димензија је 17,60 x $11 \mathrm{~m}$. Грађена је од ломљеног камена са притесаним ивицама, док је као везивни материјал коришћен кречни малтер. Зидови базилике су добро очувани и видљиви до висине од 1,80 метара. Изузетак је средишњи део апсиде и мањи део вањског зида јужног брода, који су, углавном, приликом археолошких ископавања знатно оштећени. На основу остатака зидног малтера, посебно видљивог на унутрашњој страни зида апсиде, можемо закључити да је базилика била малтерисана. Под базилике је имао малтерни премаз и његов део је сачуван унутар наоса. ${ }^{24}$

У градњи базилике уочавају се две фазе, старија и млађа. Старијој фази припада централни део базилике са олтаром (просторија А) и гробница (просторија Б). Јужни и западни брод (просторије В и Г) припадају млађој фази градње. Наиме, на основу начина градње, јасно се уочава да је овај део базилике касније дограђен.

Апсида базилике је ширине 4,90 m и дужине 2,20 m. И поред значајног оштећења, унутрашњи јужни зид апсиде још увек има очуван малтерни премаз.

Приликом археолошких ископавања, у наосу (просторија А), поред улазних врата је откривен најзначајнији налаз овог археолошког локалитета. Реч је о надгробној стели из периода принципата, која је, у овом случају, кориштена као грађевински материјал. Вероватно је служила као довратник на вратима базилике, па је услед пада поломљена на два дела. ${ }^{25}$

Јужни брод (просторија В), приближно павоугаоне основе, дужине је око 7,40 метара, док ширина варира од 2,25 метара у југозападном углу, до 2,45 метра, код уласка у гробницу. Из јужног брода, кроз врата ширине $135 \mathrm{~cm}$, се ступало у западни брод (просторија Г). Дуж западног зида ове просторије, пронађене су клупе за седење.

${ }^{24}$ Подаци су делимично преузети из Извештаја чији је аутор мр Љиљана Мандић. Овај, информацијама оскудан Извештај је требао да буде упућен „Заводу за заштиту културно-историјског и природног наслеђа Републике Српске”, од кога се тражи проглашење базилике у Мраморку за културно добро које ужива предходну заштиту. Међутим, тек залагањем једног од аутора овог приказа, готово две године касније, наведени Извештај је напокон стигао у наведену институцију. Љиљана Мандић, Извештај, Ужице, 2015, 2; За писање овог рада, поред Извештаја, користио сам се и информацијама добијеним од људи који су од првог до последњег дана учествовали у ископавањима, махом мештана, попут Љубише Ерића из Пантелића. Од великог значаја су били и подаци добијени од мр Мирка Бабића и свештеника Жељка Божића.

${ }^{25}$ Више података о овој стели биће у даљем тексту. 


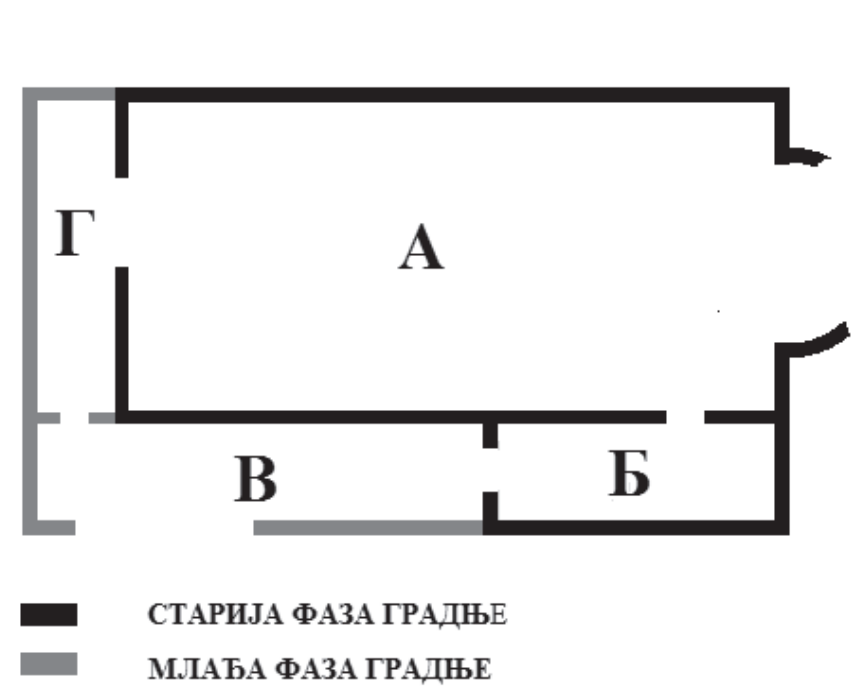

Сл. 4. Основе базилике у Мраморку

У југоисточном делу базилике, непосредно уз апсиду, налази се правоугаона гробница са делимично сачуваном конструкцијом крова на свод (просторија Б). У гробницу се могло приступити на два начина. Први је из јужног брода кроз пролаз ширине $127 \mathrm{~cm}$. Други улаз у гробници је из наксоса (просторија А) и он је ширине $111 \mathrm{~cm}$. „Гробница је зидана ређаним равним, пљоснатим каменом у више редова и ломљеним каменом са кречним малтером". ${ }^{26}$ Свод гробнице грађен је од правилно сечени блокова сиге. Гробница је димензија 230/370 цм х 89/135 $\mathrm{cm}$, док је висина $92 \mathrm{~cm}$. Улаз у гробницу је степенаст, дужине $70 \mathrm{~cm}$ и ширине $65 \mathrm{~cm} .{ }^{27}$ Унутар гробнице пронађени су скелети пет особа. Дислоциране кости могу да указују да је она још раније била опљачкана, Од гробних прилога пронађен је само део стаклене посудице.

Од покретних налаза, у шуту изнад пода базилике, пронађена је велика количина фрагмената грнчарије и стакла, једна клешта, велики број гвоздених клинова различите величине, као и више предмета од гвожђа, за сада недефинисане намене. Међутим, како су ископавања углавном вођена неплански, немогуће је навести просторије у којима су поједини артефакти пронађени.

\footnotetext{
${ }^{26}$ Љиљана Мандић, Извештај, Ужице, 2015, 2.

${ }^{27}$ Исто, 2.
} 


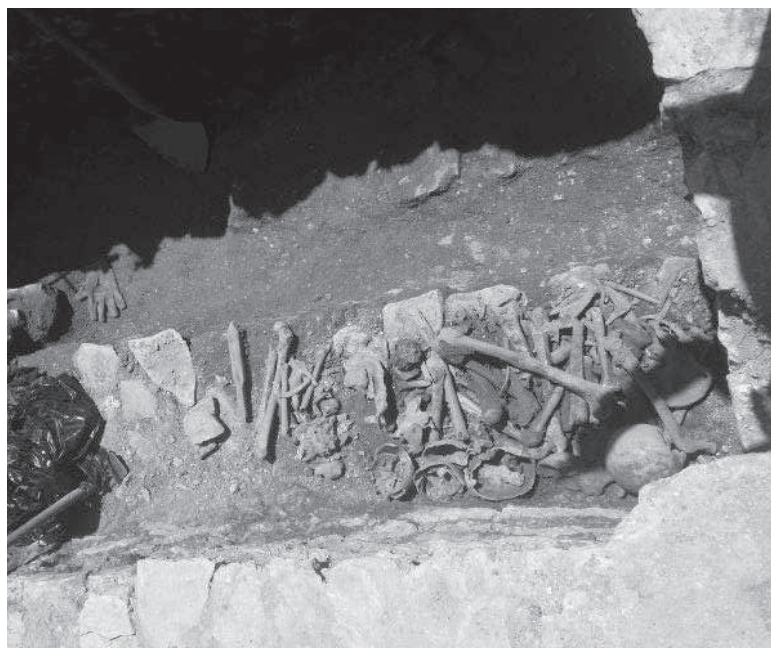

Сл. 5. Остации скелета пронађени унутар гробницее

По свему судећи, две грађевине приближно кружног облика које се налазе у близини базилике, а још увек су неистражене, највероватније представљају ранохришћанске гробнице на свод. Наиме, постојање гробница на свод унутар, али и у непосредној близини ранохришћанских базилика веома је честа појава на простору римске провинције Далмације. ${ }^{28}$ То се објашњава чињеницом да су хришћани касне антике преферирали да се сахрањују поред места где су сахрањени хришћански мученици. ${ }^{29}$ На исти начин се може објаснити присуство више особа у гробници. Затечене разбацане кости наводе на претпоставку да је гробница још раније отварана, односно да су вршени каснији укопи. ${ }^{30}$

Велика количима угљенисаног дрвета, пронађена током археолошких ископавања, а који се може видети и око остатака гробница на свод, недвосмислено указује да је базилика страдала у пожару.

Непланско, и већим делом аматерско, истраживање отежава датирање базилике у Мраморку. Ипак, анализирајући сличне налазе базилика у Босни и Херцеговини, као и прилике у позном Римском царс-

${ }^{28}$ Veljko Paškvalin, Kršćanstvo kasne antike u zaleđu Salone i Narone, 76; Edin Veletovac, Kasnoantičke bazilike u Bosni i Hercegovini, 295.

${ }^{29}$ Augustine Casiday, Fredirick W. Norris, The Cambridge History of Christianity, Vol 2, Cambridge University Press, 2008, 719-721.

${ }^{30}$ Каснији укопи познати су нам и на примеру базилике у Оборцима. Вид. Đuro Basler, Bazilika u Oborcima, Naše starine VII, Sarajevo, 1959, 66-68. 
За настанак ранохришћанских базилика у Босни и Херцеговини узима се период између IV и VI века. ${ }^{33}$ Овде су нам од велике помоћи гробнице на свод које се често појављују унутар, али и око ранохришћанских базилика. Ђуро Баслер је сматрао, на основу гробних налаза, да се гробнице на свод појављују у IV веку, а да се нарочито интезивно граде током V века. ${ }^{34}$ Сличну теорију заступа и Пашквалин који наводи да се гробнице на свод појављују током IV века, а да се са њиховом градњом највероватније престаје крајем V века, са почетком готске владавине овим подручјем. Пашквалин правилно уочава повезаност гробница на свод са ранохришћанским базиликама. Базилике које у свом саставу имају једну или више гробница на свод Пашквалин индетификује као грађевине настале у IV и V веку, док оне базилике без гробница на свод, сврстава у период VI века. ${ }^{35}$

Знамо да је једна од главних карактеристика архитектуре касне антике употреба материјала са старијих грађевина и надгробни споменика из периода принципата, за изградњу нових грађевина у V и VI веку. ${ }^{36}$ Наиме, нова религија раскида са паганским обичајима, тако да се свесно уништавају све тековине класичне римске епохе.

С обзиром на проналазак римске надгробне стеле у базилици у Мраморку, која је служила као грађевински материјал, IV век, као период настанка базилике, требао би се искључити. Наиме, У IV веку пагани представљају још увек значајан елемент у Позном Римском царству. Тек ће почетком V века многобошци доспети на маргине римског друштва и бити изложени прогонима. Такође, ако узмемо да је претходно наведена теорија о настанку гробница на свод тачна, онда би то значило да базилика није могла настати ни у VI веку. Из свега овога, по мом мишљењу, можемо закључити да је базилика у Мраморку настала у V веку. Међутим, тек ће нека будућа детаљнија истраживања дати сигуран одговор на ово питање.

\section{Горан Поповић}

\footnotetext{
${ }^{33}$ Edin Veletovac, Kasnoantičke bazilike u Bosni i Hercegovini, 277.

${ }^{34}$ Đuro Basler, Bazilika u Oborcima, 68.

${ }^{35}$ Veljko Paškvalin, Kršćanstvo kasne antike u zaleđu Salone i Narone, 111-124.

${ }^{36}$ Đuro Basler, Arhitektura kasnoantičkog doba u Bosni i Hercegovini, 32, 35; Cecil Stewart, Early Christian, Byzantine and Romanesque architecture, Vol. II, London, 1954. 17.
} 


\section{Надгробни споменик}

Надгробни споменик је откривен 2015. године у насељу Мраморак у општини Осмаци. Пронађен је на споменутом локалитету приликом истраживања ранохришћанске базилике. У контексту класификације сепулкралних споменика треба истаћи да је у овом случају ријеч о римској надгробној стели. Због секундарне употребе на овој стели евидентирана су крупна физичка оштећења. У вези са оштећењима, прво што треба истакнути је то да је горњи дио стеле, који је представљен у два реда плитких ниша с ликовним приказима, одломљен од натписног поља.

У првој ниши приказују се у рељефу три попрсја. Вјероватно је у питању пар с дјететом у средини. Све три особе су приказане одјевене у тунике дугих рукава. Лице горње, лијеве особе је уништено. Може се претпоставити да је то супруга, односно мајка. На такав закључак указује то што лијева особа носи сребрну легенгерасту фибулу украшену ланцима и привјесцима у облику бршљеновог листа. Такве фибуле се појављују на женским приказима уклесаним на надгробним споменицима пронађеним у долини ријеке Дрине (Бајина Башта, Вољевица, Црвица, Скелани, Сеча Река, Врхпоље близу Љубовије). ${ }^{37}$

Десна, мушка особа у руци држи testamentum (свитак) који треба да представља очитовање његове посљедње воље. Испод споменуте ликовне композиције уочава се иста квадратична ниша у којој се приказују у рељефу двије особе. Ликови уклесани на другој ниши вјероватно нису покојници већ су приказани насљедници који подижу стелу. Друга ниша је преломљена тако да је доњи дио тијела ликова уклесаних на споменику остао уз натписно поље (сл. 9). ${ }^{38}$

Нишу са покојницима од нише са њиховим насљедницима раздваја анимални мотив. Јасно се види да су уклесане три животиње. На први поглед, чини се да је ту представљена сцена лова, па би централна слика могла представљати зеца, а друге двије животиње су пси који нападају са лијеве и десне стране. Као што је и уобичајено за римске

\footnotetext{
${ }^{37}$ Ivana Popović, Silver jewelry of autochthonous style from South and South-East part of Roman province Dalmatia, Starinar, br. XL, Beograd, 2010, 95, 98, 110.

38 За потребе овог рада користили само фотографије надгробне стеле настала непосредно након њеног открића, које нам је уступио Милан Поповић из Гојчина, један од учесника археолошки ископавања. Разлог за то лежи у чињеници да је надгробна стела, посебно натписно поље, претрпела је велика оштећења проузрокована нестручношћу људи. Све то је утицало да се надгробан стела данас налази у жалосном стању.
} 
стеле, нише су омеђене коринтским ступовима. Ради се о глатким полуступовима стилизиране коринтске капитале са сличним орнаментом као у забату стеле.

Стела је направљена, по свему судећи, од камена вапненца. Том врстом камена, иначе је богато Подриње, те су га локалне радионице у антици обилато користиле. У иконографском смислу слична стела је пронађена на локалитету Босанска Црквина код Сребренице. ${ }^{39}$

Према класификацији античких стела са простора данашње Босне и Херцеговине, а коју је урадио Вељко Пашквалин, ова стела би припадала типу Е (варијанта Ц). Споменути аутор у ову варијанту убраја стеле правоугаоног облика, с додатком круништа, које у ликовном погледу на предњој страни имају композицију ниша у два реда с елементима архитектуре полуступова. ${ }^{40}$
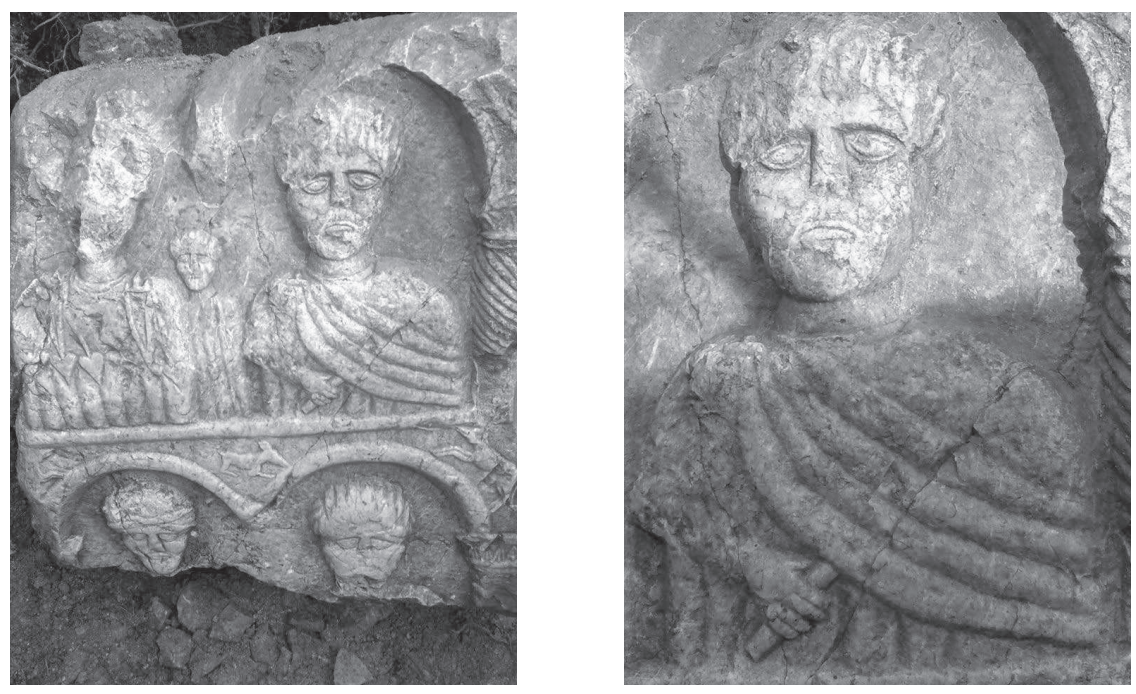

Сл. 8. Приказ мушке особе у горњој ниши

Квадратично натписно поље има украшен профилирани оквир са вегетативним мотивима. Натпис је био уклесан у осам редова. Средишњи дио натписног поља, услијед дјеловања људског фактора је

${ }^{39}$ Carl Patsch, Arheološko - epigrafska istraživanja povijesti rimske provincije Dalmacije, GZM, god XIX, Sarajevo, 1907, 431-470.

${ }^{40}$ Veljko Paškvalin, Antički sepulkralni spomenici s područja Bosne i Hercegovine, ANU BiH, Djela, LXXXIII, CBI 9, Sarajevo, 142. 
уништен, што умногоме отежава читање истог. Слова су доста уједначена што указује на рад неке доста добре локалне радионице. Хоризонталне линије које означавају редове на споменику се не виде.

Реконструкција текста:

$$
\begin{aligned}
& D(\text { is) } M \text { (anibus) } \\
& \text { T(iberio?) Cl(audio) Licen[tian]is? } \\
& \text { T(iberio?) Cl(audio) L[----]N[---] P? } \\
& \text { O [---] [an] norum XXX [---] } \\
& \text { VSPC ? .... N viv(o)s et T(?) } \\
& \text { [---] VIS posuit } \\
& \text { H(oc) m(onumentum) h(eredes) } n(\text { on) s(equatur) }
\end{aligned}
$$

Превод: Боговима Манима. Тиберију Клаудију Лицентијану, (и) Тиберију Клаудију Л(?)... који је умро са 30 година ... живио ... и најпобожнијој супрузи Т (...?), постави ... Овај споменик насљедницима не припада.

Због физичког оштећења натписног поља, реконструкција текста уклесаног на натпису је доста несигурна. Јасно је да се у првом реду

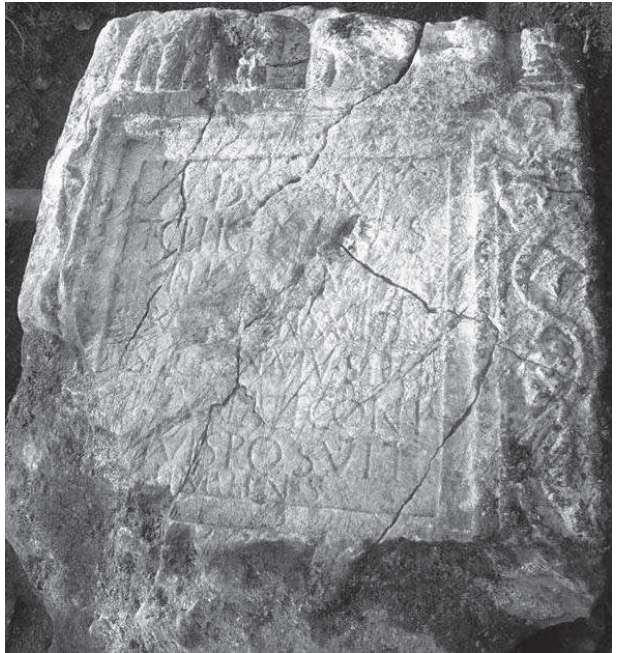

Сл. 9. Натписно поље види зазивање Мана (божанстава загробног свијета - везана за култ предака), што је уобичајна пракса код римских надгробних споменика. У другом реду је било уклесано име оца. Неупитно је да је била уклесана пуна ономастичка формула. Сачувана слова на споменику указују да је когномен оца био Licentianus (уклесан у дативу). Овај римски номен је већ потврђен у римској провинцији Далмацији. ${ }^{41}$ Синово име је било такође уклесано у пуном облику. Може се претпоставити да је његов когномен био исто Licentianus или изведеница тог когномена Licentinus.

${ }^{41}$ Géza Alföldy, Die Personnennamen in der römischen Provinz Dalmatia, Heidelberg, 1969, str. 230 ; András Mócsy, Nomenclator provinciarum Europae Latinarum et Galliae Cisalpine cum indice inverso, Dissertationes Pannonicae, Budapest, 1983, 164. 
Нажалост, сачувана слова не омогућавају прецизнију реконструкцију. Слово Р на крају трећег реда можда означава агномен сина. Судећи према овој реконструкцији, отац је умро са 30 година. Мајчино име је било уклесано на крају петог и на почетку шестог реда. Нажалост, не може се реконструисати, али је извјесно да је био уклесан само гентилни номен и когномен. Кратица $H M H N S$ која се појављује на крају натписа указује да се ова гробница не насљеђује. Ова скраћеница се ријетко јавља на натписима у унутрашњости римске Далмације. ${ }^{42}$ Такође треба истаћи да је и клаудијевски номен изузетно риједак на простору унутрашњости римске Далмације. Судећи према ономастици, чини се реалним претпоставити да се у овом случају ради о досељеницима у Подриње.

Када је ријеч о датацији настанка споменика, једино што је неупитно је то да је terminus ante quem настанка споменика период владавине цара Клаудија (41-54. година). На први вијек би указивала скраћеница $\mathrm{h}(\mathrm{oc}) \mathrm{m}$ (onumentum) $h$ (eredes) $n$ (on) s(equatur) која се у Далмацији јавља углавном на натписима из првог стољећа. Пуна ономастичка формула је такође више повезана са првим и другим вијеком. С друге стране, изглед фигура (одјећа и накит) које су уклесане на споменику се могу довести у везу са другим и трећим вијеком. Сходно наведеном, када се сумирају сви елементи, чини се најлогичнијим овај споменик датирати у прву половину другог вијека.

Архитектонска композиција стеле указује да је ријеч о локалној елити. У контексту времена када је споменик настао трошкови клесања оваквог једног споменика су били доста велики. Самим тим, овакви споменици су били доступни само локалним елитама. Нижи слојеви становништва обично су као форму надгробног споменика користили ципусе, ситуле и урне чија израда је била доста јефтинија.

Ово је до сада једини пронађени епиграфски споменик на ширем подручју. Најближи епиграфски налази потјечу са подручја Зворника и веома су малобројни. Свакако треба споменути да је само један од тих споменика спулкарног карактера попут овог из Осмака. ${ }^{43}$ Текст друга два споменика са подручја Зворника јасно указује да су то вотивни, односно почасни споменици. ${ }^{44}$

${ }^{42}$ Veljko Paškvalin, Antički sepulkralni spomenici s područja Bosne i Hercegovine, 30.

43 ------] / [------] / [---]IIP [---] / [-----] / [-]S[--]VL AC[--]C[---]5 / [-] Aur(elio?) Pa[]pico(?) [--] / [--] viventes sibi [---] (ILJug I, 82)

${ }^{44}$ I(ovi) O(ptimo) M(aximo) / Co(ho)r-/tali / [------? (ILJug I, 84)[[Imp(eratore) [Cae]s(are) M(arco) O[p]ell(io) Sever(o)]] / [[M[ac]rin[o Pio Fel(ici)] Au[g(usto)] p(ontifice) m(aximo) trib(unicia)]] / [[p[ot(estate) co(n)]s(ule) [---]I?I?I?I?[---]I?]] / [[[-]I?[--]M?[---]N[---]I? [---]A?N?S]] / macellum vi ignis conflagr $<a>$ tum 5/ curante 


\begin{tabular}{|c|c|c|c|c|c|}
\hline $\begin{array}{c}\text { ОНОМАСТИЧКИ } \\
\text { ОБЛИК } \\
\text { УКЛЕСАН НА } \\
\text { НАТПИСУ }\end{array}$ & $\begin{array}{l}\text { ПРАЕ- } \\
\text { HOMEH }\end{array}$ & НОМЕН & ГЕНТИЛЕ & $\begin{array}{l}\text { ПОДАЦИ О } \\
\text { ОСОБАМА }\end{array}$ & ПОРЕКЛО \\
\hline $\begin{array}{l}\text { T(iberio?) Cl(audio) } \\
\text { Licen[tian]is }\end{array}$ & Tiberius & Claudius & Licen[tian]is & 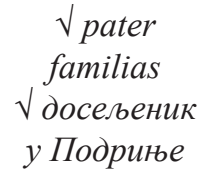 & италско \\
\hline $\begin{array}{c}\text { T(iberio?) Cl(audio) } \\
L[----] N[---]\end{array}$ & Tiberius & Claudius & $\begin{array}{l}\text { Licentianus ili } \\
\text { Licentinus }\end{array}$ & $\begin{array}{l}\sqrt{ } \text { filius } \\
\text { familias }\end{array}$ & италско \\
\hline$T(?)[---] N A T[A] E$ & непозна-то & непозна-то & непознато & $\begin{array}{l}\sqrt{ } \text { mater } \\
\text { familias }\end{array}$ & $\begin{array}{c}\text { италско или аутохт- } \\
\text { оно }\end{array}$ \\
\hline
\end{tabular}

Табеларни приказ ономастичке и просопографске анализе текста уклесаног на надгробном епиграфском споменику из Мраморка код Осмака. 
Недостатак епиграфских споменика у овом дијелу источне Босне треба свакако приписати лошој истражености терена.

Сходно томе, треба истаћи да је најближе потврђено римско насеље у Горњој Петровици код Калесије. Ту су пронађени римски зидови грађени од камена вапненица, а као везивни материјал кориштен је кречни малтер. На том локалитету такође су пронађени уломци римских посуда, оружја (врх стријеле) и римски бакрени новац. Научници претпостављају да се на том локалитету налазила касноантичка утврда. Остаци утврђења се јављају и на простору Ђурђевика. ${ }^{45}$ Међутим, сви ти налази углавном се вежу за касну антику, док би ова стела из Мраморка могла потврђивати континуитет насељености и у принципату.

Због свог правилног облика, споменици раније епохе, у периоду касне антике, су кориштени као грађевински материјал што потврђује и овај налаз надгробне стеле из Мраморка код Осмака.

Text reconstruction:

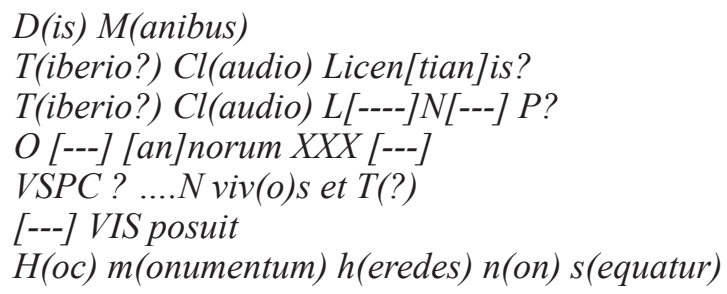

Амре Шачић

\section{СПИСАК СКРАЋЕНИЦА}

ANU BiH - Akademija nauka i umjetnosti BiH

GZM - Glasnik Zemaljskog muzeja u Sarajevo

CBI - Centar za balkanološka ispitivanja, Akademija nauka i umjetnosti

CIL III - Corpus Inscriptionum Latinarum III (ed. Th. Mommsen), Berlin 1873: Supplementa 1889-1902.

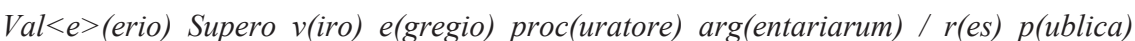
Dom(aviana) ad pristinam / faciem restituit XXI Kal(endas) (CIL 03, 08363b = CIL 03, $08363+$ p. 2328, $117=$ CIL 03, 12733).

${ }^{45}$ Arheološki leksikon BiH, Tom (I- III), Arheološki leksikon Bosne i Hercegovine, (ed. BORIVOJ ČOVIĆ), Tom I-III; Mape 1-4, 1988, Sarajevo, 108. 
ILJug - Incriptiones Latinae quae in Iugoslavia inter annos MCMXL et MCMLX repertae et editae sunt (ed. A. et J. Šašel), Situla 5, Ljubljana 1963 (št. 1-451); Inscriptiones Latinae quae in Iugoslavia inter annos MCMLX et MCMLXX repertae et editae sunt (ed. A. et J. Šašel), Situla 19, Ljubljana 1978 (št. 452-1222); Incriptiones Latinae quae in Ingoslavia inter annos MCMII et MCMXL repertae et editae sunt (ed. A. et J. Šašel), Situla 25, Ljubljana 1986 (št. 1223-3128)

\section{ЛИТЕРАТУРА}

Arheološki leksikon Bosne i Hercegovine, (ed. BORIVOJ ČOVIĆ), Tom I -III; Mape 1 - 4, 1988, Sarajevo.

Géza Alföldy, Die Personnennamen in der römischen Provinz Dalmatia, Heidelberg, 1969.

Tomislav Anđelić, Kasnoantička bazilika u Cimu kod Mostara, GZM, arheologija, Sarajevo, 1974.

Tomislav Anđelić, Kasnoantičke bazilike u Cimu i Žitomisličima kod Mostara, Arheološki vestnik 29, Ljubljana, 1978.

Tomislav Anđelić, Neki objekti kasnoantičke sakralne arhitekture u okolici Mostara, Dolina rijeke Neretve od prethistorije do ranog srednjeg vijeka (Znanstveni skup, Metkić 4-7. X 1977. god.), Hrvatsko arheološko društvo, Split, 1980.

Đuro Basler, Arhitektura kasnoantičkog doba u Bosni i Hercegovini, Sarajevo, 1972.

Đuro Basler, Bazilika u Oborcima, Naše starine VII, Sarajevo, 1959.

Đuro Basler, Kršćanska arheologija, Crkva na kamenu, Mostar, 1986.

Đuro Basler, Gradina, Sapna, Zvornik, Arheološki leksikon, tom II, Sarajevo, 1988.

Đuro Basler, Kršćanska arheologija (II izdanje), Crkva na kamenu, Mostar, 1990.

Đuro Basler, Spätantike und frühchristliche Architektur in Bosnien und der Herzegowina, Wien, 1993.

Ivo Bojanovski, Iz rada Arheološkog referata Zavoda, Naše starine, XI, Sarajevo, 1967.

Ivo Bojanovski, Prilozi za topografiju rimskih i predrimskih komunikacija i naselja u rimskoj provinciji Dalmaciji (s posebnim obzirom na područje Bosne i Hercegovine), Prilog proučavanju antičkih naselja $i$ kominikacija u istočnoj Bosni, Godišnjak, knj. XIX, Sarajevo, 1981.

Рајко Бошковић, Монографија општине Осмаци, Зворник, 2013. 
Edin Veletovac, Kasnoantičke bazilike u Bosni i Hercegovini, Radovi, knj. XVII/3, Sarajevo, 2014.

Edin Veletovac, Provincija Dalmacija u V stoljeću, magistarski rad, Sarajevo, 2013.

Eduard Vorliček, Rimske starine u Branjevu, kotar Zvornički, GZM, god. VIII, Sarajevo, 1896.

Бојан Вујиновић, Рановизантијске базилике у Бакинцима, Бања Лука, 2014.

Тибор Живковић, Црквена организащија у српским земљама, Београд, 2004.

Milica D. Kosorić, Spomenik Mitrinog kulta iz okoline Zvornika, Članci i građa za kulturnu istoriju istočne Bosne, knj. VI, Tuzla, 1965.

Амијан Марцелин, Историја, Боград, 1988.

Љиљана Мандић, Извештај, Ужице, 2015.

Petar Mirković, Manastir Panagjur, GZM, god. I, Sarajevo, 1889.

András Mócsy, Nomenclator provinciarum Europae Latinarum et Galliae Cisalpine cum indice inverso, Dissertationes Pannonicae, Budapest, 1983.

Veljko Paškvalin, Antički sepulkralni spomenici s područja Bosne i Hercegovine, ANU BiH, Djela, LXXXIII, CBI 9, Sarajevo.

Veljko Paškvalin, Kučište, Donji Šepak, Zvornik, Arheološki leksikon, tom II, Sarajevo, 1988.

Veljko Paškvalin, Kršćanstvo kasne antike u zaleđu Salone i Narone - Arheološka istraživanja kasnoantičkog kršćanstva u Bosni i Hercegovini, Sarajevo, 2003.

Carl Patsch, Epigrafsko pabirčenje, GZM, god. VII, Sarajevo, 1895.

Carl Patsch, Arheološko - epigrafska istraživanja povijesti rimske provincije Dalmacije, GZM, god. XIX, Sarajevo, 1907.

Ivana Popović, Silver jewelry of autochthonous style from South and South-East part of Roman province Dalmatia, Starinar, br. XL, Beograd, 2010.

Vaclav Radimsky, Ostanci rimskih naseobina u Šipragi i Podbrgju, zatim starobosanski stećci u Šipragi i uz Vrbanju u Bosni, GZM, god. IV, Sarajevo, 1892.

Vaclav Radimsky, Arheološke crtice iz Bosne i Hercegovine, GZM, god. V, Sarajevo 1893.

Vaclav Radimsky, Arheološke crtice, GZM, god. VII, Sarajevo, 1895.

Dimitrije Sergejevski, Epigrafske bilješke, GZM, god LIII, Sarajevo, 1941 (1942).

Dimitrije Sergejevski, Starohrišćanska bazilika u Klobuku, GZM, arheologija, Sarajevo, 1956. 
Dimitrije Sergejevski, Bazilika u Dabravini (Revizija), GZM, arheologija, posebno izdanje, Sarajevo 1956.

Dimitrije Sergejevski, Bazilika u Mokrom, GZM, arheologija, Sarajevo, 1961.

Cecil Stewart, Early Christian, Byzantine and Romanesque architecture, Vol. II, London, 1954.

Ćiro Truhelka, Prilozi rimskoj arheologiji Bosne i Hercegovine, GZM, god. IV, Sarajevo 1892.

Franjo Fiala, Prilozi arheologiji Bosne i Hercegovine, GZM, god. V, Sarajevo, 1893.

Augustine Casiday, Fredirick W. Norris, The Cambridge History of Christianity, Vol 2, Cambridge University Press, 2008.

Irma Čremošnik, Ulice, Šetići, Zvornik, Arheološki leksikon, tom II, Sarajevo, 1988.

Кључне речи: рано хришћанство, касна антика, базилика, надгробна стела, Мраморак, Босна и Херцеговина.

A. Šačić, E. Veletovac, G. Popović

\section{NEWLY DISCOVERED EARLY CHRISTIAN BASILICA IN NORTHEASTERN BOSNIA AND HERCEGOVINA}

In 2013, archeological research was started in the small mountain village of Mramorak, in the northeastern Bosnia and Hercegovina. After two years of research, the remains of early Christian basilica were discovered. Basilica extends towards west - east. Dimension of basilica is $17,60 \times 11 \mathrm{~m}$. It was bult of broken stone, while lime mortar was used as a binding material. Based on the remains of the wall mortar, especially visible on the inside of the apse wall, we can conclude that the basilica was plastered. In the southeastern part of the Basilica, next to the apse, there is a rectangular tomb with a partially preserved roof structure. Dimension of the tomb is $230 / 370 \mathrm{~cm} \times 89 / 135 \mathrm{~cm}$, while the height is $92 \mathrm{~cm}$. The entrance to the tomb is staggered, $70 \mathrm{~cm}$ long and $65 \mathrm{~cm}$ wide. Five skeletons were found within the tomb. Dislocated bones may indicate that tomb was earlier robbed. It seems Basilica was bult in the 5th century. During archaeological excavations, roman tombstone is discovered beside the front door of room A. This tombstone (stelae) is dated to the first half of the second century. Stelae consists of two niche and field with inscription. First niche is shown as relief of a couple 
with the child in the middle. All three persons are shown dressed in long sleeve kirtle. The face of the upper, left person is destroyed. It can be assumed that this is a wife, or a mother. Right male person in hand has testamentum, which means his last will. The text was engraved in eight lines. The central part of the inscription field is destroyed, which makes it difficult to read. 